\title{
Jorge Sacido-Romero
}

\section{Universidade de Santiago de Compostela, España}

ORCID: https://orcid.org/oooo-0003-0302-0990

\section{Luis Miguel Varela-Cabo \\ Universidade de Santiago de Compostela, España}

ORCID: https://orcid.org/oooo-0002-0569-0042

\section{Achilles Redivivus: "Pink Floyd: The Wall" as a Modern-Day "Iliad"}

\section{Resumen}

El presente artículo desarrolla la similitudes estructurales, temáticas y caracterológicas que existen entre Pink Floyd: The Wall de Alan Parker y La Ilíada de Homero, interpretando ambas obras como épicas centradas en la ira del héroe, sus consecuencias y su resolución. El argumento está organizado en torno a tres temas centrales: la pérdida como causa de la inacción y el sufrimiento del héroe infligido por un poder inhumano en el contexto de la guerra; la ley en tanto fundamento del orden social capaz de restablecer el equilibrio; el amor como fuerza unificadora para la armonía individual y colectiva. Comienza con una explicación de las razones de por qué se escoge la película en vez del álbum como objeto de análisis antes de pasar a presentar la tesis y los objetivos principales y de justificar la elección de la crítica arquetípica como marco metodológico de referencia. Para establecer las características definitorias del arquetipo aquíleo es necesario reequilibrar la concepción de Aquiles como ejemplo de poder masculino, llamando la atención sobre su lado más humano, que es el realmente dominante en la Ilíada, haciendo referencia ya en esta parte a las similitudes que conectan a Aquiles y a Pink, el personaje principal de la película. El resto del artículo examina cómo tanto la Ilíada como Pink Floyd: The Wall giran en torno a héroes que se embarcan en un proceso de autodescubrimiento que no sólo implica la transformación de su posición subjetiva dentro de la sociedad sino que también articula un conjunto de valores alternativos a los dominantes en sus respectivas formaciones sociales. En el desarrollo de este argumento no se pierden de vista las especificidades de los periodos históricos en que ambas obras se enmarcan y a los que responden.

\section{Palabras clave:}

La Iliada; Pink Floyd: The Wall; pérdida; ley; amor; épica

\section{$\approx$ Abstract}

This article elaborates on the structural, thematic and characterological similarities between Alan Parker's Pink Floyd: The Wall and Homer's Iliad, reading both works as epics that revolve around the hero's wrath, its consequences and its resolution. The argument is organised around three central topics: loss as the cause of the heroes' inaction and suffering inflicted by an inhumane power in the context of the war; law as the foundation of a social order that would redress the balance; love as the binding force of individual and collective harmony. It explains the reasons why the film, and not the album, is selected as the object of discussion before moving on to the presentation of the article's central thesis and objectives and the justification of the choice of archetypal criticism as the methodological frame of reference. In establishing the defining features of the Achillean archetype that Parker's film reproduces, it becomes necessary to counterbalance Achilles' status as the example of virile might by highlighting his more human and humane dimension, the truly dominant aspect of the Iliad, already referring in passing to the similarities linking Achilles to Pink, the film's central character. The rest of the article elaborates on how both the Iliad and Pink Floyd: The Wall feature two heroic figures that embark on a journey of selfdiscovery that not only entails the transformation of their subjective position inside society, but also the articulation of a set of values alternative to those that operate in their respective social formations. In developing this line of argument, the article does not lose sight of the specificities of the historical periods in which both narratives are embedded and respond to. 
fter their early period (1967-1972) and in the space of a decade (1973-1983), British rock band Pink Floyd released a string of so-called concept albums, collections of musically and/or thematically intertwined pieces which often tell a story and exhibit a circular pattern (Elicker 200I, 229). Such is the case of Pink Floyd's The Wall (1979), an album which contains in sketch the plotline of a character's vicissitudes and ends with an echo of the opening bars. Alan Parker's Pink Floyd: The Wall, the album's cinematic version, was released in 1982 . The present article compares Parker's film to Homer's Iliad. Both works are epics that revolve around the hero's seclusion (the rock star's and the best of warriors', respectively), its consequences and its resolution. While attending to their similarities, the article never loses sight of the works' historical specificities. It develops the idea that Achilles, the main character in the Iliad, and Pink, the film's central figure, are instances of the same archetype. Both works and the central characters they feature share three interlinked central topics: (I) loss as the cause of the heroes' wrathful inaction and suffering arbitrarily inflicted by a self-serving inhumane structural power in the context of the war, (2) law as the foundation of a social order invoked to redress the disrupted balance and (3) love as the binding force constitutive of individual and collective harmony. Sections 4, 5 and 6 below will develop in full the striking characterological, thematic and structural resemblances between two works that otherwise stand very far apart. Prior to this, Section 2 frames the ensuing discussion within the coordinates of archetypal criticism, while section 3 is devoted to redefining the Achillean hero type against the common monolithic view that Homer's character is the epitome of invincible virile might. The remaining of the present section justifies the choice of Parker's film over Pink Floyd's album as the object of discussion.

The first reason for our choice is that Pink Floyd: The Wall, as a film, increases the degree of "narrativity" or "emplotment" (Abbott 20I4) already found in The Wall. Viewers have a clearer idea of the story they are being told than those who just listen to the album or attend a concert. In the course of a phone conversation with EMI executive Bob Mercer, Parker said: "'Look at The Wall, a number-one album in goodness knows how many countries, an obvious narrative line; where is the film?"” (Parker 1982b, I025). Parker's interest in the filmic adaptation of the album chimed with Roger Waters' desire to make The Wall into a movie. When he met Waters, the leader of the band, Parker was surprised by how much work he had already put in trying to push forward the filmic project with the help of cartoonist Gerald Scarfe (1982a, 2025). In 198 I, Waters had the script ready, which was later revised by Parker. The filming began in early September of that year and the movie premiered in Cannes on May 23, 1982 (Gonthier and O'Brien 2015, 103-6).

The second reason for choosing the film instead of just the album has to do, paradoxically, with the power of music. David Detmer, who rightly singles out modern capitalist "alienation" as the central theme in Pink Floyd's concept albums, comments on how the critical message the band tried to communicate was not only conveyed through the lyrics, but also, of course, through the music. The main characteristic of Pink Floyd's musical style, "its leisurely pacing", would potentially provoke a more "thoughtful response" on listeners (Detmer 2007, 65). This effect was to be distinguished from that of other British bands of the time such as "the kind of rush or excitement that Led Zeppelin or The Sex Pistols would put in play" $(2007,65)$. But Pink Floyd's music, as Detmer states, "require[s] repeated listening" (2007, 63; italics in the original). Listeners and audiences are expected to grasp the mutually reinforcing interrelation between logos (words, discourse, lyrics) and phone (sounds, music). Pink Floyd's music is hermeneutically demanding because the connection between logos and phone is sometimes evident (as the sound of the cash register and the coins in "Money", in the album The Dark Side of the Moon), but most often it is not. The problem faced by a rock band that tried to transmit their critical stance concerning the historical context of their time was that the sound of their music had such a strong appeal that it drained the work of its concrete historical meaning and transformed it into a simple source of aesthetic pleasure.

In their concerts, Pink Floyd had recourse to props of all sorts to complement both their music and lyrics with a visual support to help to put their message across. But, unfortunately for the band and for Waters, the desirable effect of receptiveness towards what they tried to communicate was not really achieved. A crisis broke during the 1977 Animals tour, on which they used props like inflatable pigs floating around in concert venues. The growing frustration with the audience reached its peak in an Animals concert in Montreal, in which Waters spotted a teenager in "mindless ecstasy" so that he "leaned into the fan's face and let fly a great gob of spit" (Schaffner 2005, 222). This episode sparked Waters' creativity resulting in the composition of The Wall (Rose 2002, 85). However - and this could be considered the third reason for choosing the film - Waters' initial creative move was not musical but cinematic. Lyrics and images, rather than music, went first in his mind: "I was working on ideas for the movie even before I started writing music for The Wall" (Dallas 20r3).' Lyrics and images - more concrete media of expression in that their referents are more easily identifiable - thus genetically predated sound production, music, which is a more abstract art form (Jameson 198I, 239). Waters, it seems clear, first tied the message to be communicated in The Wall to logos and to images that develop along a preconceived cinematic narrative line, with phone, music, added at a later stage in the creative process. Waters' interest in cinema as a vehicle of expression undoubtedly comes from film's virtue to combine music, images and words more effectively when it comes to communicating meaning. What Parker's film adds to The Wall is a greater degree of concreteness to the set of characters, themes, feelings and events referred to in the songs. Furthermore, it transforms the storyline implicit in the album into an explicit filmic narrative that renders the message in a clearer manner. The music is integrated as a major element in the work, but its powerful and mesmerising appeal is counterbalanced by what is seen onscreen.

\section{Achilles as Pink's Archetype}

Early in their career (1968), Pink Floyd had a filmic project in mind which would revolve "around a story line ("like the Iliad", Waters said) as opposed to the traditional pop fare of the day" (Thompson 2013, I54). Though the project eventually fell through for lack of funding, it is clear that Waters was interested in Homer's text as a possible source of inspiration for an unconventional musical film. Homer's transformation of pre-existing oral sources on the Trojan War into a unified long narrative resulted in an unconventional epic poem featuring an unconventional epic hero: Achilles. 
In the Iliad, Homer conveyed a message that resonates contemporary audiences. Thus, Grant Farred (2OII) compared Achilles' withdrawal from the war against the Trojans, who had "done nothing" to him (Iliad I.I53), to boxer Muhammad Ali, who refused to fight in the Vietnam War declaring in I966 that "No Viet Cong ever called me Nigger"' (quoted in Farred 20II, IIO3). In open "defiance of the powers that be", Achilles and Ali speak "the language of principled retreat" (Farred 20II, IIO3). Farred considers "Achilles the recluse [...] the forerunner of Great Garbo, Howard Hughes, Syd Barrett, and Marcel Proust" (200I, IIO3). The present article argues that there are even more substantial reasons to include Pink in the list of figures who bear a basic resemblance to Achilles. Pink, Roger Waters' and the band's corporate alter ego as well as a synecdoche of postwar England, is to be taken as Achilles' heir. He shares not only Homer's hero's ethics and poetics of principled withdrawal but also Achilles' articulation of individual and social values alternative to the dominant ones. Pink Floyd, a leading band of what is often referred to as "British progressive rock" (Ankers 1999, 43I), addressed the growing social crisis of the time (riots, strikes, unemployment, etc.) and criticised the monetarist policies implemented by those in power, beginning with the Labour Government of James Callaghan (1976-1979) and continuing with Margaret Thatcher's ultraliberal agenda from 1979 onwards. What is specific of Pink Floyd's sociopolitical stance is that theirs is an immanent critique of the system, carried out from within the system itself rather than from the position of confrontational outsider taken by punk rock bands and their "negation of everything: 'No Feelings', 'No Fun', 'No Future'" (Worley 2017, 4). ${ }^{2}$ In The Wall (both album and film) and its companion album The Final Cut: A Requiem for the Postwar Dream (1983), the criticism of the sociopolitical context is not given in the form of the negation of everything. Pink Floyd's is an indictment of Power's betrayal of the spirit of the postwar consensus as well as an endorsement of an alternative future based on the values and ideals that spirit had inspired. Sacido-Romero and Varela-Cabo (2006) elaborated this line of argument in reference to Pink Floyd: The Wall, providing a close reading of the musical/auditory and visual strategies employed in the cinematic narrative to communicate this message. Their conclusion was that the film articulates an ethico-political alternative to Britain's dehumanised historical present grounded on love and justice (Sacido-Romero and Varela-Cabo 2006, 50-6). The present article draws on this previous work to bring to light the remarkable resemblances linking the cinematic narrative of Pink Floyd: The Wall to Homer's Iliad, where an ethico-political alternative is sketched along similar lines.

Unlike the album and like Homer's Iliad, Pink Floyd: The Wall does not exhibit the circular pattern so frequent in concept albums (Elicker 200I, 229). The film's suppression of the final echo of the initial notes can be interpreted as a musical hint at the character's eventual liberation from the cycle of tormenting repetition. Looking at Pink Floyd: The Wall through the lens of Homer's Iliad endows Pink with the epic status of a hero that rises against the historically specific evils of his day. In the movie, the model of the popular idol is deconstructed in such a way that he emerges as an ethical hero of our day, though he remains a rock star. Likewise, Achilles' universal consideration as the archetype of the invincible warrior must be qualified when one reads the Iliad. The central character comes across as the embodiment of principled withdrawal who ultimately endorses the ethics of love and justice. This characterological archetype, redefined as an ethical hero instead of just a mighty warrior, may exist independently of rewritings of the Iliad or stories featuring Achilles. Thus, the comparative analysis of Homer's epic and Parker's film is ultimately an exercise of archetypal criticism, which is the critical approach that leads to the discovery of similar patterns in works far removed from each other (Lee 1993b, 508). As Alvin A. Lee further explains, archetypal critics accept the fact that "[a]rchetypes are present in literature however they come to be there" (1993a, 4). The view that archetypal criticism is dated and reductive must be opposed. A simple search of the Word "archetype" on the Internet suffices to find out that much critical work has been published recently. As to the criticism that it distorts, flattens and dehistoricises narrative works to make them fit a pre-given grid or pattern, the answer is that this need not be so if the critic is careful, as he/she must, to take into account the historical context in which works subject to comparison are embedded (Hawkins 1985, 15).

\section{Achilles, human(e), all too human(e), and Pink, too}

As recent research has shown, Achilles figures prominently in modern popular music (Cavallini 2oro, González Vaquerizo 2020). Thus, in Bob Dylan's "Temporary like Achilles" (I966), the epic hero is reduced to the role of a guard that keeps off a girl's rejected lover. Led Zeppelin's "Achilles Last Stand" (I976) features an exile who yearns for his home not in classical Greece but in Britain. Homer's character, however, is more recurrently present in the musical genre of heavy metal, where he stands out as the embodiment of the masculine ethos of courage and power (Cavallini 20ı,, II9-26; González Vaquerizo 2020, 63-5).3

But Achilles' mythical status as the archetypal demi-god possessed of invincible might must be qualified by taking into account his more human and humane side, which clashes with the set of ideals in relation to which he was and continues to be celebrated as the outstanding example of virile courage. In the Odyssey (XI.6227), Homer had already warned his readers against this onedimensional interpretation by having the ghost of dead Achilles express his prizing of ordinary life over fame and glory. William R. Nethercut's analysis of Achilles' particular "epic journey", though published long ago, is still very helpful in tackling the apparent inconsistency in Achilles' characterisation as, at once, a human and a superhuman figure, with the former prevailing over the latter. Going by the standard pattern of progression common to heroes of folk sagas and epic narratives all around the world as established by Joseph Campbell (2008 [I944]) Achilles stands out as an exceptional character.

The similarities among the heroes studied by Campbell, a prominent archetypal critic himself, allow him to speak of a "monomyth" $(2008,23)$. Achilles' epic journey is, however, radically different from that of the heroes of the monomyth, Odysseus included. ${ }^{4}$ Instead of venturing into a fantasy land and fighting off monsters as other epic and legendary heroes do, Achilles remains "static" inside "a perfectly ordinary tent" (Nethercut 1976, I), refusing to go on fighting the Trojans. ${ }^{\text {T }}$ The novelty of the Iliad lies in the fact that it features a hero as "an inwardly existing personality" and whose "journey is a psychological one" (Nethercut 1976, I). Like Parker's film, Homer's epic plot actually renders the process of a hero's self-exploration, through which both his position among his people and the set of social values they endorse are reformulated. For his community of warriors, Achilles has a double role: he is at once the mightiest of warriors and the monster whose unyielding 
refusal to fight stands as the major obstacle in the Greeks' path to victory. Pink exhibits a similar duplicity as he is at once the great rock superstar whose withdrawal into a hotel room impedes the normal running of the profit-making rock industry. Timothy White informed Schaffer that, for Waters, rock and war were comparable in their subservience to the interests of the powerful. White quoted Waters as saying that "rock and roll is becoming greed disguised as entertainment, just as war has become greed disguised as politics" (Schaffner 2005, 222).

Achilles' wrathful withdrawal into his tent and into himself is first caused by the loss of Briseis, a maid won as a war prize who is taken away by the leader of the army, Agamemnon. It is in Achilles' attachment to Briseis where another strikingly new feature in the Iliad is to be found, one which emerges from the hero's journey of self-discovery and which grows beyond itself to become a universal value to be embraced. Achilles declares that he truly loves Briseis, that she is the object of his sincere affection and not a prize to be enjoyed. Pink, secluded in his hotel room, is visited by a groupie, a beautiful young woman who stands as a prize for his fame. Pink rebuffs her sexual advances first by patiently concentrating on the TV set and, later, by destroying every piece of furniture in the room in an outburst of wrath. He still loves his wife, whom he lost because he focused on his musical career only.

The novelty of the hero's affection for a woman is something exceptional in the epic tradition to which the Iliad belongs. Yet, love transcends Achilles' relationship with Briseis or with his close friend, Patroclus, whose death he avenges. Love and affection play a central role in the hero's progress of (self-)discovery and eventual "spiritual and psychological reintegration with mankind" (Nethercut 1976, 9). Nethercut explains how Achilles embraces love as a value which not only applies to past ties of affection to those closest to him (Briseis, Patroclus or Peleus), but also to those who, in principle, are the Greeks' archenemies (Priam, king of Troy, who humbly begs Achilles to give him back the dead body of his son, Hector) and to humankind in general. Love is expanded to a point that it becomes a universal value in the Iliad as a result of the hero's epic journey of exploration away from and back to society (Nethercut 1976, I4). As developed below, love as both eros (sexual) and, particularly, agape (social), are similarly endorsed as desirable values in the narrative of Pink Floyd: The Wall.

Nethercut maintains that the images engraved in the shield that Hephaestus crafts for him overnight contains all that Achilles must learn (1976, I4). The shield's scene of the city at war accords well with Achilles' status as warrior, which, as has been seen, is not really the principal focus of the Iliad. It is to the other scene, the city at peace, to which the novelty of the plot and the hero's epic journey relates more closely. This is a scene of harmony framed within the limits of the natural course of the seasons and of ordinary social life. Nethercut mentions in passing an element of the picture which deserves more attention than he accords to it: namely, the fact that the city at peace does also contain "disagreement and makes room for litigation" in the scene of a trial going on in the public space (1976, I4). Therefore, the lesson to be learned is not only about the desirability of love as the universal harmonising force within the limits of natural and human life, but also the inevitability of discord at the heart of harmony which must be dealt with by recourse to the law. The judicial institution mediates conflicts and restores harmony. Loss and recovery through the power of love and the law must come together in the end if the "integration of self within the universe" is to be achieved (Nethercut 1976, I4). Love and the law also come together at the end of Parker's film as Pink brings to a halt the tormenting state he is in in the song "Stop" and its accompanying images that give way to a judicial scene ("The Trial"), out of which the message of love is solemnly communicated in the lyrics of anthemic song "Outside the Wall".

\section{Loss}

The Iliad begins, as all epic texts after Homer usually do, with an introduction of the poem's topic: namely, Achilles' anger and its terrible consequences for the joint army of Greeks in their war against the city of Troy. The cause of Achilles' wrath was his loss of Briseis after Agamemnon, the commander of the Greek army, took her away from him (Iliad I.244). Angered Achilles poured his rancour on Agamemnon for acting as an irrational, self-serving, cowardly and arbitrary leader whose power he did not recognise as legitimate. The hero eventually decided he would not fight anymore and retired to his tent.

In Pink Floyd: The Wall the central character, Pink, the leader of the band, also refuses motu proprio to go on participating in the alienating - to use Farred's own words - "fanfare of the rock industry" (20II, IIO). The present-day dynamics of the show business that torment Pink are effectively presented in the film through visual counterpoint as being analogous to, or even conterminous with, World War II, a past event traumatically attached in Pink's mind to the loss of his father, an ordinary life sacrificed dishonourably and in vain by powers past and present (Sacido-Romero and Varela-Cabo 2006). Pink's loss of both his father and, as discussed below, his wife, are akin to Achilles' loss of Briseis and, much later in the poem, of his dear friend, Patroclus, all of them sacrifices inflicted by overriding forces that instrumentalise human life for their own spurious interests.

Achilles is well aware of this injustice when he confronts high commander Agamemnon's abusive rule, as Pink also is in the film, when in the initial song, "When the Tigers Broke Free" (not included in the album), his mind bitterly recreates the circumstances in which "the High Command / Took my daddy from me" (Waters I98I, 2). Achilles calls Agamemnon a "king who feed[s] on [his] own people" because he sends his soldiers to die while he remains in a safe place and takes most of the credit and the plunder (Iliad I.23I). Achilles' protest is echoed in Book II by outspoken soldier Thersites, who calls for desertion and praises Achilles (Iliad II.22542). Ordinary men (Thersites) and extraordinary men (Achilles) come together in their indictment of tyrannical, self-interested rule. Pink voices his criticism along similar lines in "When the Tigers Broke Free". His father, a low-rank officer depicted in the film as the very image of the English gentleman, died in the battle of Anzio (1944) along with "a hundred ordinary lives" to hold a bridgehead against the enemy, the Nazi army. They had been "all left behind" to their tragic fate by the higher-rank officers (Waters I98I, 2). The traumatic losses that Achilles and Pink suffer impel them to quit the ongoing war and withdraw to the private space of, respectively, a tent and a luxurious suite in an American hotel. Attempts are made to make them abandon their confinement and inaction, which they eventually do in the final turning point leading to the conclusion of both narratives. 
$\simeq$ Achilles' loss is a double loss not just because he loses Briseis and his dear friend Patroclus, but also because, by being forced to give up the maiden, the hero is deprived of, on the one hand, his honour (Iliad I.244), and, on the other, his object of passionate attachment, a woman he considers his wife (Iliad IX.34I-3). ${ }^{6}$ It is not only that Achilles "equates her [Briseis] to his wife and disregards her status as a war prize" (Wright 2016, II6; Nethercut 1976,2 ), since Briseis also envisions their life together as a married couple back in Pthia (Iliad XIX.298-9).

Pink's loss is, like Achilles', a double loss. Of course, as the film shows, he had lost both his father (killed in battle) and his wife (who had run away with an anti-nuclear activist due to Pink's systematic unresponsiveness, immersed as he was in his role of rock and roll star). But, moreover, the dual nature of Pink's loss is articulated in the filmic narrative as Power's historical betrayal of the socio-political consensus reached after World War II for the implementation of the welfare system. In the postwar period, it was agreed that war sacrifice and discontent should give way to a radical change in the status quo through State protection of the whole population (Sinfield 2004, I4-24). This more humane, caring social system was eroded as in the period in which The Wall was recorded and Pink Floyd: The Wall was scripted and produced (1979-I982), the time in which PM Margaret Thatcher implemented ultraliberal policies. Pink's loss of his father was caused by the State's heartlessness during the war, a conflict that the film makes analogous to Britain's eventual endorsement of unfettered capitalist money-making dynamics that breed walledin, alienated individuals like Pink himself. As the song "Empty Spaces" and the images that accompany it make clear, human connections and affective bonds are eradicated and confined to the past.

Pink, secluded in his room and showing signs of mental derangement, rehearses an imaginary solution for his and the nation's predicament: namely, fascism, with him as the leader of a fervid crowd of British concert-goers. Immediately afterwards, he takes to the streets leading a paramilitary group that begins a series of rallies, installing scaffolds in the public space and raiding houses to supress racial contamination and difference. All this is brought to a halt as the filmic narrative reaches the final turning point with a return to the American concert venue. Pink is again isolated, this time behind the unlocked door of a toilet, singing in a way that resembles quiet speech the lyrics of the song "Stop". This marks the beginning of the articulation of a desirable alternative solution developed in the conclusion of the narrative. Similarly, in the Iliad, the final turning point is preceded by Achilles' act of wrathful violence. Brought out of his tent in rage for the death of Patroclus, he behaves as a fanatic warlord who even profanes Hector's corpse. As in Pink Floyd: The Wall, an alternative is sketched in the conclusion of Homer's epic.

\section{Law}

Pink Floyd: The Wall lays bare the evils of late capitalism of which the rock industry was a part. The band's concept albums increasingly concentrated on capitalist society as the target of attack. From "Money" in The Dark Side of the Moon (1973), through "Have a Cigar" or "Welcome to the Machine" (Wish You Were Here [1975]), to the Orwellian Animals (1977), the indictment of contemporary (British) society became wider and deeper until the band reached its breaking point with the production of a most stringent immanent critique of a system which included themselves as targets: The Wall. The very same channel that allowed them to reach wide audiences proved a disabling force when trying to get their adversarial message across to a discerning public they did not have. This frustrating lack of communication with the public epitomised the alienation characteristic of capitalist society. By building a wall between the band and the public on stage during the concerts of The Wall tour, alienation became not just thematised but was actually performed (Ackermann 20I2, 16).7 Furthermore, the band's engagement on the erection of a wall onstage was a metaphor of their active role in the alienating dynamics at work in society at large and, as such, it can be taken as a self-accusatory gesture. Similarly, the filmic version of the album, whose central character is corporately called "Pink Floyd", can be read as an act of self-deconstruction in which the band's guilty subservience to alienating (economic) power is exposed. But, as developed below, neither The Wall nor Pink Floyd: The Wall conclude in such a radically pessimistic manner as they eventually rehearse a way out of this tormenting cycle of alienation and seclusion. And neither does Homer's Iliad.

If capitalist tyranny is exposed in Pink Floyd: The Wall, what type of power is actually contested by Achilles in the Iliad? Do Achilles' words and (in)actions, as is the case with Pink's, point to something larger than themselves? As in the case of Pink Floyd: The Wall, the examination of the unfair structural order Homer's hero reacts against makes it imperative to approach the Iliad historically. Dean C. Hammer (1997; 1998) helps clear the path through the thicket of Homeric scholarship on history and politics in the Iliad, while at the same time it lends support to the comparison of this work and Pink Floyd: The Wall.

Achilles is forced to obey Agamemnon and give up his beloved Briseis to the commander of the Greek army. Where does Agamemnon's power derive from? Hammer reviews the work of Homeric critics like M. I. Finley (I979) and Walter Donlan (I980), who view the world depicted in the Iliad as that of the Dark Age (late 2nd millennium BC) and, thus, "pre-political": that is,

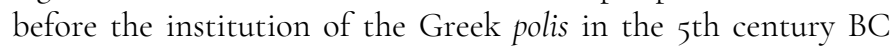
(I997, I-3, 5, I4; I998, I-3). Written in the 8th century BC, the Iliad does not simply reflect the world of the Dark Age, but also articulates Homer's awareness of the historical progress towards the polis or the city-state taking place in his time (Hammer 1997 , I4). The world in the Iliad is not yet the fully-formed polis - a selfconscious civic community, with formalised and authoritative economic and political institutions - but no longer that of the Dark Age. Conflicts and their mediation are not simply private or personal issues regulated by a law derived from the leader's might and lineage, but are quite often the object of public debate.

Though Achilles may seem to stand for a centrifugal period previous to the process of centralisation, he is also absolutely instrumental in making Agamemnon's rule emerge as tyrannical and his authority be exposed as illegitimate in public assembly (Hammer 1997, 3; 1998, 14). Like Pink, who resists the tyranny of capital that thwarts political action in the service of (in this case) impersonal economic power, Achilles contests pre-political might and opens up the space of the political. If grief-stricken and, at some points, wrathful Pink stands for the band as a whole and for the British people at a particular point in history, wrathful and, at one point, weeping Achilles stands for the people's discontent, triggering the contestation of Agamemnon's authoritarian modes as expressed by a simple soldier. 
$\simeq$ In the Iliad, Achilles finally breaks his seclusion (Iliad XVIII) and heads for the battlefield to avenge the death of Patroclus, his dear friend. Patroclus had begged Achilles (Iliad XVI) to let him borrow his armour and shield to push back the Trojan forces. He was eventually killed by Hector. Achilles does then enter battle again, but this time with the sole purpose of avenging Patroclus' death by killing Hector (Iliad XXII). When Achilles is preparing for battle, god Hephaestus forges overnight a new shield for Achilles. The god adorns the shield with a series of scenes, the latter becoming "the most commonly noted instance of awareness of polis life" in the Iliad (Hammer 1997, 15). The poem goes into a detailed ekphrastic, quasi-filmic account of Hephaestus' engravings, as if to supplement Achilles' revenge with a message that relates his action to a world that stands in contrast with that of the Dark Age still embodied by Agamemnon. The shield tells the tale of "two cities" (Iliad XVIII.490), one at peace and the other at war. The latter's description (Iliad XVIII.508-605) soon progresses into peacetime depictions of people harvesting the fields and feasting (Iliad XVIII.54I-605). Most importantly for the present argument, however, is the reference to a trial going on in the "market place" of the city at peace, the first one to be described. This scene depicts the workings of a juridical institution following established procedures in the mediation of conflicts. Furthermore, this is a daily scene removed from the context of the court and the elite of kings and warriors, involving, rather, common people. Gregory Nagy delves into the resonances of this trial scene in the poem's narrative as a whole and affirms: "the logic of the story-within-a-story, the litigation scene, spills over the story of Achilles" $(2003,82)$.

The decision in the trial scene is whether the plaintiff should accept ransom from the defendant's murder of his relative or demand the latter's death in revenge. Though the shield's story is left open in the sense that the final decision of the people (laos) concerning the most just argument (dikē) to solve the case is not known, it is not so in the framing story of the Iliad. In the latter, Achilles does avenge the death of his dear Patroclus by taking Hector's life but eventually accepts ransom from Hector's father, Priam, in compensation for Patroclus' death so that he lets the Trojan king take his son's body back to be given the honourable burial with which the narrative closes (Iliad XXIV) (Nagy 2003, 83). Even more important for the present argument is Nagy's view concerning the fact that Achilles is ultimately responsible for Patroclus' death as he had not accepted Agamemnon's ransom for his dispossession of Briseis and had let his friend impersonate him in the battle against the Trojans (2003, 84). Thus, Achilles does not only resemble the plaintiff in the shield's litigation scene, but also the defendant (Nagy 2003, 84). He is simultaneously the passive victim and the guilty perpetrator, just like Pink (Floyd), who is both victim of, and active participant in, the tormenting and alienating capitalist dynamics depicted in the filmic narrative as an ongoing war.

According to Nagy's reading, therefore, in the final turning point of the Iliad, Achilles' words and actions are to be related to the juridical scene engraved on his newly-forged shield. Achilles enacts the two possible solutions to a murder case in a sequence: first revenge and afterwards ransom, with the latter gaining preeminence over the former. Similarly, in Pink Floyd: The Wall, the final turning point is directly related to justice and the law as Pink decides to break his seclusion in order "to know / Have I been guilty all this time?" (Waters I98I, 86; italics added). While in the Iliad there is no explicit verdict from "an arbitrator" (Iliad XVIII.5OI) containing the most righteous judgment (dike), in the film Pink does come before the court to be judged. The totalitarian solution is, thus, abandoned, and there is an appeal to the traditional institution of the Law embodied by the Crown's prosecutor and the judge who dictates an unambiguous sentence after finding Pink guilty of the charges. The past is invoked and reinstated in the dramatic song "The Trial". 9 The scene is set in a dark space and exhibits the features of a music-hall performance acted by menacing animated figures. The first to speak is the prosecutor, who Waters described in the film script as someone "invented by PINK in his subconscious, as a tool with which to pick the locks of his own guilty feelings" (Waters I98I, 86). The prosecutor addresses the judge saying:

\begin{abstract}
The crown will plainly show
The prisoner who now stands before you

Was caught red handed showing feelings,

Showing feelings of an almost human nature.

(Waters I98I, 86)
\end{abstract}

Next, Pink's teacher, wife and mother are summoned to give testimony against him, which they do in the most vicious, vehement manner. Thus, the teacher laments he had not been allowed to discipline him appropriately as his "hands were tied. / The bleeding hearts and artists / Let him get away with" (Water I98I, 86). He asks the judge to "let me hammer him today" (Waters I98I, 86). He is followed by the "defendant's wife", who recriminates Pink for not talking to her "more often" and asks him if he had "broken any / Homes up lately" (Waters I98I, 88). She asks the judge to be left alone with Pink just for five minutes, but, as in the teacher's case, she is not granted this petition. Finally, the mother zeroes in the scene like the Nazi war airplane that had killed Pink's father in the Anzio trenches. As in the case of the teacher and the wife, her request remains unanswered. The mediation of these conflicts is left to the judge alone, not to the revengeful witnesses, who would, if allowed to, perpetuate Pink's alienation and grief.

This whole animation scene - set in some dark underground recess, presided over by the imposing, obscene figure of a judge and opened by the prosecutor's speech before the court - should not only be interpreted as Pink's recourse to the traditional institution of the Law. It is also the rendition of the ultimate foundation of the Law precisely because it rests on the Crown (invoked by the prosecutor in his initial words) as the mystic body that incarnates Justice and the Nation as a whole (the Nation being also judged at a particular point in history for which Pink's character functions as a synecdoche). All the violence displayed in the scene has to do with what Jacques Derrida called "Force of Law: The "Mystical Foundation of Authority", to quote the title of the published translation of a lecture delivered in I989. Derrida uncovers the implicit violence hidden in the administration of justice and expressed in English phrases like "to enforce the law" (1992, 5, I0; italics added). The operative functioning of the law and the effective administration of justice ("dike" [Derrida 1992, $6,20,36])$ rest on a foundational violence - not the police or the repressive apparatus of the State, but a foundational moment which has no place in time precisely because it is mystical (Derrida I992, $13-4) .{ }^{\text {I0 }}$

"The Trial" exposes the Law's foundational violence by what is seemingly an otherwise debunking caricature of normal and 
$\sim$ unequivocally British judicial proceedings. In this light, Waters' description of the scene as "subconscious" is in line with Derrida's idea of the silenced, repressed, walled-in act that founds legal and judicial authority (Derrida 1992, I3-4). In his search for an order that works as an alternative to alienating madness, fascism and capitalism, Pink has reached the rock bottom of the judicial edifice, the one that truly holds the promise of redressing the balance upset by inimical forces and heralds the coming of a better individual and collective future outside the wall. Dike (justice), as the future foundational institution of the polis prefigured in Achilles' shield and indirectly enacted by the hero in the denouement of Homer's Iliad, is invoked by Pink as a past, traditional institution whose timeless foundation would be the guarantor of a desirable order. There not being any witnesses of the defence, the judge pronounces his decision: "I sentence you to be exposed before / Your peers. / Tear down the wall" (Waters I98I, 90).

\section{Love}

Max Horkheimer and Theodor W. Adorno argued that the defining feature of modern capitalist society was the "abrogation of everything that is inherently binding" (I999, 93). In their incessant march forward, mass-production, mass-consumption and profit-making dissolve close, interhuman bonds, replacing them with monetary ties, with the so-called cash nexus (Marx and Engels 2000). It is to the restoration of those close interhuman bonds abrogated in commodified social life that Pink is sentenced in the end, as reproduced in the quote at the end of the previous section. The bizarre judge defecates scenes of Pink's past life while a chorus of voices repeats the command "Tear down the wall" (Waters I98I, 90). The imaginary disposal of all the bricks that made up the wall of Pink's alienation gives way to a realist still image of a wall that is blown into pieces after thirty seconds of nearly insupportable waiting. Pink is released from his unbearable contracted seclusion through an explosion which, unlike the previous explosions heard and seen throughout the film, is not destructive but, rather, liberating, opening up the space for change. As the smoke caused by the explosion dissipates and the sound decreases, a realistic street scene appears onscreen with ordinary British people walking among the debris of what seems a truck crash or the leftovers of a riot while the initial solemn notes of "Outside the Wall" are heard in the soundtrack. Firemen extinguish a fire while people struggle their way across, till the camera focuses on three children (a blond boy, a dark-

haired boy and a black girl) collecting pieces like milk bottles in boxes and bricks in a toy truck, while discarding with disgust the rag inside an unused Molotov cocktail and emptying its contents. ${ }^{\text {II }}$ As the image freezes and the title credits are shown, the lyrics are sung:

All alone, or in twos,
The ones who really love you
Walk up and
down outside the
Wall
[...]
The bleeding hearts and the artists
Make their stand. (Waters I98I, 94)

The collapse of the wall after the violent explosion decreed by institutional law as the vehicle of justice heralds the restoration of human bonds of affect, compassion, fellowship, sympathy, in sum, of love. A new society is being born, now represented by the child figures who unequivocally stand for multiracial Britain. Love operates outside the wall of alienation ("The ones who really love you / Walk up and down outside the ( Wall"), yet isolation is always a possibility, though now described as maddening, perverse and degenerate: "Banging your heart against some / Mad buggers['] / Wall" (Waters 1981, 94; italics added). Furthermore, "artists", previously rendered as both victims and agents of alienation, walk together with those who are particularly compassionate towards their fellow human beings ("bleeding hearts"), both forcefully expressing the need to comply with the imperative of love, not an easy task: "when they've given you their all / Some stagger and fall - as after all / It's not easy" (Waters I98I, 94). Love and justice finally stand as the alternative to pervading alienation and lack of communication.

Echoes of the conclusion of Homer's Iliad in Book XXIV are again substantial. Achilles, who avenged Patroclus' death by killing Hector, is visited by Priam, Hector's father, who begs Achilles to accept ransom for Patroclus' murder and let him take his son's body with him back to Troy. Standing on his knees before Achilles, Priam begs him to put himself in the place of his own father and accept "gifts beyond number" for Hector's body (Iliad XXIV.5O2). Moved to pity by Priam's evocation of his father, Achilles takes Priam's hand and both weep (Iliad XXIV.503-16).

Achilles, partly responsible for the loss of Patroclus, is moved to accept ransom, a juridical compensation depicted in the shield he carried to battle now supplemented by the compassion he feels for the enemy. Love (eros and, particularly, agapē) and justice (dikē), as in the case of Pink Floyd: The Wall, is the course taken outside the world/wall dominated by tyrannical forces that transform people into puppets (Parker i982a) or "nonentities" (Iliad I.23I). In the city at peace depicted in Achilles' shield, the ekphrastic description of the judicial scene is preceded by another in which love is communally celebrated with music and dance.

\section{Conclusion}

Homer's poem transcends the limits of epic, heroic ethos of war and external honour (Seaford 1994, 25; Nethercut 1976, 3), in ways similar to Pink Floyd: The Wall, a cinematic narrative which points beyond the tormenting and alienating dynamics of capitalism to which Pink (Floyd) contributed. In the film's conclusion, the seed of a new society of peers, of caring brothers and sisters, is planted. The sun shines in a real urban space as if joining the celebration of what is now beginning, no longer in the solitary open field that punctuates the film and functions as a moment of relief in the midst of chaos and suffering. The conclusion of the film's narrative contains a message of hope for the materialisation of the postwar world dreamt of by the soldier in "The Gunner's Dream" (The Final Cut). This world is based both on the retrieval of close, interhuman bonds and the institution of the law as the necessary instrument of social justice, a world in which "you can speak out loud about your doubts and fears" and "everyone has recourse to the law" (Pink Floyd r983).

After justifying the preference for the The Wall's filmic version over the album as the primary object of this research, this article has highlighted structural, thematic and characterological similarities linking Homer's epic to Parker's film. All this has been done in support of an archetypal reading of both works that attends to their 
$\sim$ distinctive sociohistorical contexts. Archetypal criticism as a methodology brings to light similar patterns in works that otherwise stand far apart temporally and culturally, indicating how transhistorical topics and concerns may come under different guises. Much effort has been put to counterbalance the common view that Achilles is the epitome of invincible virile might, as in the Iliad he emerges first and foremost as a humane character, just like Pink, the central character in Pink Floyd: The Wall. Both heroes embark on a journey which is rendered as an inner exploration out of which they emerge to convey similar messages to those closest to them, to their respective societies, to humankind at large, and to us, readers and viewers. Loss and suffering, retreat and wrath, love and care for fellow human beings, and justice and the law as the guarantors of social harmony are substantial components linking both works and the characters they feature across the ages.

\section{Works Cited}

ABBOTT, H. Porter. 2014. "Narrativity." In The Living Handbook of Narratology, ed. Peter Hühn, John Pier, Wolf Schmid and Jörg Schönert. Hamburg: Hamburg University. http://www.lhn.unihamburg.de/article/narrativity (Last access: December I7, 2020).

ACKERMANN, Zeno. 2or2. "Rocking the Culture Industry/ Performing Breakdown: Pink Floyd's The Wall and the Termination of the Postwar Era." Popular Music and Society 35 (I): I-23.

ANKERS, Niel. 1999. "Progressive Rock." In Encyclopedia of Contemporary British Culture, ed. Peter Childs and Mike Storry, 43I-2. London: Routledge.

CAMPBELL, Joseph. 2008 (1944). The Hero with a Thousand Faces.

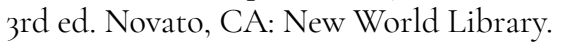

----. 2019. "The Homeric Legends: A Championship of Humanity and Brutality." The Joseph Campbell Foundation. https:// www.youtube.com/watch? $=$ pMDw 3 UtAbq8 (Last access: October 16, 2020).

CAVALLINI, Eleonora. 20ıo. "Achilles in the Age of Steel: Greek Myth in Modern Popular Music." Conservation Science in Cultural Heritage 9 (I): II3-30.

CROSSLEY, Nick. 2015. Networks of Style, Sound and Subversion: The Punk and Post-Punk Worlds of Manchester, London, Liverpool and Sheffield, 1975-8o. Manchester: Manchester UP.

DALE, Pete. 20I2. Anyone Can Do It: Empowerment, Tradition and the Punk Underground. Aldershot: Ashgate.

DALLAS, Karl. 2013. "A Roger Waters Interview, September 22, 1982." The Karl Dallas Archive of Contemporary and Popular Music. https://kdarchive.wordpress.com/2013/02/18/a-roger-watersinterview-september-22-1982/ (Last access: December 19, 2020).

DERRIDA, Jacques. 1992. "Force of Law: The 'Mystical Foundation of Authority." In Deconstruction and the Possibility of Justice, ed. Drucilla Cornell, Michel Rosenfeld and David Gray Carlson, 3-67. Trans. M. Quaintance. New York: Routledge.
DETMER, David. 2007. "Dragged Down by the Stone: Pink Floyd, Alienation, and the Pressures of Life." In Pink Floyd and Philosophy: Careful with that Axiom, Eugene!, ed. George A. Reisch, 6I-8o. Chicago: Open Court.

DINES, Mike and Matthew Worley, eds. 20I6. The Aesthetic of Our Anger: Anarcho-Punk, Politics and Music. Colchester: Minor Compositions.

EDMUNDS, Lowell. 1989. "Commentary on Raaflaub." In Proceedings of the Boston Area Colloquium in Ancient Philosophy Vol. 4, ed. John Cleary and Daniel Shartin, 26-33. Lanham: UP of America.

ELICKER, Martina. 20or. "Concept Albums: Song Cycles in Popular Music." In Word and Music Studies: Essays on the Song Cycle and on Defining the Field, ed. Walter Bernhart and Werner Wolf, 227-48. Amsterdam: Rodopi.

FARRED, Grant. 20II. "Achilles, Celebrity Recluse." PMLA I26 (4): $11 \mathrm{IO}-9$.

GONTHIER, David F. Jr. and Timothy O'Brien. 2015. The Films of Alan Parker 1976-2003. Jefferson, NC: MacFarland.

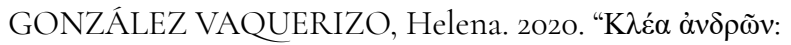
Classical Heroes in the Heavy Metal." In The Hero Reloaded: The Reinvention of the Classical Hero in Contemporary Mass Media, ed. Rosario López Gregoris and Cristóbal Macías Villalobos, 5I-722. Amsterdam/Philadelphia: John Benjamins.

HAMMER, Dean C. I997. “Who Shall Readily Obey?' Authority and Politics in the Iliad." Phoenix 5I (I): I-24.

----. 1998. "The Politics of the Iliad." The Classical Journal 94 (I): I-3O.

HAWKINS, Anne Hunsaker. 1985. Archetypes of Conversion: The Autobiographies of Augustine, Bunyan, and Merton. Eugene, OR: Bucknell UP.

HOMER. I951. Iliad. Trans. R. Lattimore. Chicago: The U. of Chicago P.

----. 2006. Odyssey. Trans. I. Johnston. Arlington: Richer Resources.

HORKHEIMER, Max and Theodor W. Adorno. 1999. Dialectic of Enlightenment. Trans. J. Cumming. New York: Continuum.

JAMESON, Fredric. 198I. The Political Unconscious: Narrative as a Socially Symbolic Act. Ithaca, NY: Cornell UP.

JENKINS, Philip.I996. "Bricks in the Wall: An Interpretation of Pink Floyd's The Wall." In The Berlin Wall: Representations and Perspectives, ed. Ernst Schürer, Manfred Keune and Philip Jenkins, 205-13. New York: Peter Lang.

LAGUNA-MARISCAL, Gabriel and Manuel Sanz-Morales. 2005. "Was the Relationship between Achilles and Patroclus Homoerotic? The View of Apollonius Rhodius." Hermes: Zeitschrift für Klassische Philologie I33 (I): 120-3. 
LEE, Alvin A. 1993a. "Archetypal Criticism." In Encyclopedia of Contemporary Literary Theory: Approaches, Scholars, Terms, ed. Irena R. Makaryk, 3-5. Toronto: U. of Toronto P.

I993b. "Archetype." In Encyclopedia of Contemporary Literary Theory: Approaches, Scholars, Terms, ed. Irena R. Makaryk, 508. Toronto: U. of Toronto P.

MACAN, Edward. 2007. "Theodor Adorno, Pink Floyd, and the Psychedelics of Alienation." In Pink Floyd and Philosophy: Careful with that Axiom, Eugene!, ed. George A. Reisch, 95-II9. Chicago: Open Court.

MARX, Karl and Frederick Engels. 200o. Manifesto of the Communist Party. https://www.marxists.org/archive/marx/ works/I848/communist-manifesto/ (Last access: October 3I, 2019).

MENKE, Christoph. 20I0. "Law and Violence." Law \& Literature 22 (I): I-I7.

NAGY, Gregory. 2003. Homeric Responses. Austin: U. of Texas P.

NETHERCUT, William R. I976. "The Epic Journey of Achilles." Ramus 5 (I): I-I7.

PARKER, Alan. I982a. Pink Floyd: The Wall. London: Goldcrest Films International.

I982b. "Pink Floyd - The Wall: The Making of the Film."

American Cinematographer, October, I025.

PINK FLOYD. 1979. The Wall. New York: CBS.

----. 1983. The Final Cut: A Requiem for the Postwar Dream. Hollywood: Harvest/EMI.

ROSE, Phil. 2002. Which One's Pink? An Analysis of the Concept Albums of Roger Waters and Pink Floyd. Burlington: Collector's Guide.

SACIDO-ROMERO, Jorge and Luis Miguel Varela-Cabo. 2006. "Roger Waters' Poetry of the Absent Father: British Identity in Pink Floyd's The Wall." Atlantis 28 (2): 45-58.

SCHAFFNER, Nicholas. 2005. Saucerful of Secrets: The Pink Floyd Odyssey. London: Helter Skelter.

SEAFORD, Richard. 1994. Reciprocity and Ritual: Homer and Tragedy in the Developing City-State. Oxford: Clarendon.

SINFIELD, Alan. 2004. Literature, Politics and Culture in Postwar Britain. New York: Continuum.

THOMPSON, Dave. 2013. Roger Waters: The Man behind the Wall. Milwaukee: Backbeat.

WATERS, Roger. 198I. The Wall: Screenplay. https://archive.org/ details/PinkFloydsTheWallMovieScript/page/ni (Last access: October I7, 2019).

WEINSTEIN, Deena. 2007. "Roger Waters: Artist of the Absurd." In Pink Floyd and Philosophy: Careful with that Axiom, Eugene!, ed.
George A. Reisch, 8I-93. Chicago: Open Court.

WORLEY, Matthew. 20I7. No Future: Punk, Politics and British Youth Culture, 1976-1984. Cambridge: Cambridge UP.

WRIGHT, Ian. 2016. "The Wife of Achilles." Mnemosyne: A Journal of Classical Studies 69: 113-8.

ŽIŽEK, Slavoj. I989. The Sublime Object of Ideology. London: Verso.

----. I99I. Looking Awry: An Introduction to Jacques Lacan through Popular Culture. Cambridge: The MIT P.

\section{Acknowledgements}

This article benefits from the collaboration of the Research Group Discourse and Identity (ED43IC, 2019/oor, Xunta de Galicia) and the research network Twenty-First-Century Anglophone Literatures (RED2OI8-IO2678, AEI, FEDER, 20I9). The authors would like to thank Dr. Laura Lojo Rodríguez and the anonymous reviewers of Oceánide for their invaluable suggestions and comments. Thanks are also due to Drs. Federico L. Silvestre, Xavier De Donato Rodríguez, Valerià Paül Carril and, again, Laura Lojo for joining us in the search for new ideas.

\section{$\approx$ Notes}

I. Animals seems to have also had a cinematic prehistory before becoming an album (Dallas 2013).

2. The punk movement was a much more complex phenomenon than the phrase "confrontational outsiders" above would make us think. It has been the object of serious research (Dale 2or2; Crossley 2015; Dines and Worley 2016; Worley 2017).

3. For a list of examples of heavy metal songs featuring Achilles as the central character see González Vaquerizo (2020, 65).

4. There is no mention of the Iliad or Achilles in Campbell's The Hero with a Thousand Faces. Elsewhere, he refers to Achilles as just "the great physical he-man [...] representing the masculine attitude, the sheerly brutal masculine attitude, and the relationship to women as that of master to property", while endowing the Trojan warrior Hector with a human(e), affective dimension (Campbell 20I9).

5. References to Richmond Lattimore's I95I translation of the Iliad and to Ian Johnston's 2006 translation of the Odyssey are by book and line number.

6. For the homoerotic nature of Achilles' strong affection towards Patroclus see Laguna-Mariscal and Sanz-Morales (2005, I20).

7. Apart from Detmer's chapter, the themes of alienation and inauthentic communication in Pink Floyd in general, with particular references to The Wall, are discussed in other essays in Pink Floyd and Philosophy (2007). See, in particular, Macan (2007) and Weinstein (2007). 
8. In the film, "Pink" is called "Mr Floyd" by the operator when he tries unsuccessfully to speak to his wife on the phone.

9. In British culture there is a persistent portrayal of or allusion to the gentleman as a defining element of national identity (Berberich 2007, 25).

Io. For a philosophical argument that also develops the connection Law/violence see Menke (2010). Along with violence, the action dramatised in "The Trial" is also permeated with obscenity (for instance, the judge defecates in the end). Along with violence and related to it, obscenity has been distinguished as another unlikely feature of the law (Žižek 1989, 37; 199I, I46).

II. The interpretation of the bottle the dark-haired boy holds in his hands as a Molotov cocktail is taken from Rose (2002, I34). Bombs have no place in this (re)new(ed) world outside the wall.

Título:

Achilles Redivivus: Pink Floyd: The Wall como una Ilíada moderna

Contact:

jorge.sacido@usc.es 